\title{
SEJARAH SOSIAL-BUDAYA MASYARAKAT CINA BENTENG DI KOTA TANGERANG
}

\section{SOCIAL-CULTURAL HISTORY OF CINA BENTENG IN TANGERANG CITY}

\author{
Euis Thresnawaty $\mathbf{S}$ \\ Balai Pelestarian Nilai Budaya Bandung, \\ Jln. Cinambo 136 Ujungberung Bandung \\ e-mail: euisthresnawaty62@gmail.com
}

\begin{abstract}
Abstrak
Tangerang terletak di bagian barat Pulau Jawa, yang merupakan tetangga ibu kota Jakarta. Tangerang, yang semula berada di wilayah Jawa Barat sejak tahun 2000 berada dalam wilayah Provinsi Banten, memiliki banyak keunikan pada masyarakatnya, salah satunya adalah adanya pembauran antaretnis yang berjalan harmonis antara etnis Sunda, Jawa, Melayu, dan Cina. Banyak komunitas etnis Tionghoa di Indonesia, tetapi komunitas etnis Tionghoa yang ada di Kota Tangerang memiliki keistimewaan tersendiri. Mereka yang dikenal dengan sebutan Cina Benteng telah mampu berbaur dengan pribumi secara alami. Etnis Tionghoa yang tinggal di Kota Tangerang hampir seperempat dari keseluruhan jumlah penduduk Kota Tangerang. Oleh sebab itu kebudayaan Tionghoa banyak mewarnai kebudayaan setempat. Mereka memiliki budaya khas tersendiri yang berbeda dengan warga Tionghoa umumnya. Penelitian ini dilakukan untuk mengetahui bagaimana kondisi sosial budaya masyarakat Cina Benteng pada masa kolonial hingga kemerdekaan. Metode yang digunakan adalah metode sejarah yang meliputi heuristik, kritik, interpretasi, dan historiografi. Dari hasil penelitian ini dapat diketahui ternyata ada beberapa perubahan sosial pada masyarakat Cina Benteng, misalnya ketika masa kolonial mereka dapat dikatakan hidup berkecukupan karena mereka dianggap partner dalam berdagang sementara saat ini kehidupan mereka cenderung sangat sederhana.
\end{abstract}

Kata kunci: sejarah sosial, Cina Benteng, Tangerang.

\begin{abstract}
Tangerang is located in the western part of Java Island, which is a neighbor of the capital city of Jakarta. Tangerang, which was originally located in West Java, and since the year of 2000 are in the province of Banten. Tangerang have so many unique in their society, one of is the existence of ethnic intermingling that runs harmony between the ethnic of Sundanese, Javanese, Malay, and Chinese. Many Chinese community in Indonesia, but the Chinese community in the city of Tangerang has its own privileges. They are known as Cina Benteng(Chinese Fortress) has been able to blend in with the natives naturally. Chinese people who live in the city of Tangerang nearly a quarter of the total population of the city of Tangerang Therefore, the Chinese culture has affected much local culture. They have a distinctive culture that is different from the Chinese people in general. This study was conducted to determine how the social and cultural conditions of China Fortress in the colonial period to independence. The method used is the historical method which includes heuristics, criticism, interpretation, and historiography. From these results it can be seen apparently there are some social changes in Chinese society Fortress, for example when the colonial period they can be said to live well because they are considered partners in the trade while currently they tend to be very simple life.
\end{abstract}

Keywords: social history, Cina Benteng, tangerang 


\section{A. PENDAHULUAN}

Interaksi antaretnis dapat mengakibatkan perubahan sosial budaya dan penetrasi kebudayaan. Perubahan sosial budaya adalah sebuah gejala berubahnya struktur sosial dan pola budaya dalam suatu masyarakat. Perubahan sosial dan budaya merupakan gejala umum yang terjadi sepanjang masa dalam setiap masyarakat. Perubahan ini terjadi sesuai dengan hakikat dan sifat dasar manusia yang selalu ingin melakukan perubahan. Tiga faktor yang dapat memengaruhi kebudayaan sosial adalah tekanan kerja dalam masyarakat, keefektifan komunikasi, dan perubahan lingkungan (Sulistiyani, 2011: 124). Perubahan budaya juga dapat timbul akibat perubahan lingkungan masyarakat dan kontak dengan kebudayaan lain.

Sementara itu dari sisi sejarah, sejarah sosial mempunyai garapan yang sangat luas dan beragam. Banyak sejarah sosial yang berhubungan dengan sejarah ekonomi sehingga menjadi sejarah sosialekonomi atau yang berhubungan dengan budaya, menjadi sejarah sosial-budaya. Di negara-negara yang sedang berkembang seperti Indonesia, kegiatan penelitian dan penulisan sejarah sosial masih sedikit terutama yang bercorak sejarah sosial daerah.

Sekalipun sejarah sosial sudah merupakan gejala baru dalam penulisan sejarah sejak sebelum Perang Dunia II, tetapi sebagai sebuah gerakan yang penting baru mendapat tempat sekitar tahun 1950an. Di Perancis aliran penulisan Annales yang dipelopori oleh Lucien Febvre dan Marc Bloch menjadi modal bagi generasi baru penulis sejarah sosial yang semakin kuat kedudukannya dalam dunia penulisan sejarah (Kuntowidjojo, 1999: 39).

Ada hal yang menarik untuk dikaji mengenai keberadaan komunitas Tionghoa yang tersebar di setiap kota di Indonesia dari sisi sejarah sosialnya. Komunitas Tionghoa pada umumnya menempati suatu tempat yang disebut Kampung Pecinan. Salah satunya adalah komunitas Tionghoa yang berada di Kota Tangerang, dikenal dengan nama masyarakat Cina Benteng.

Cina Benteng merupakan

komunitas Tionghoa yang memiliki keunikan tersendiri. Tidak seperti Tionghoa peranakan pada umumnya, etnis Cina Benteng berkulit gelap dan matanya pun tidak sipit. Nenek moyangnya adalah Cina Hokkian yang datang ke Tangerang dan tinggal turun temurun di kawasan Pasar Lama. Kawasan Pasar Lama atau Jalan Ki Samaun sekarang, adalah pemukiman pertama masyarakat Cina Benteng. Kawasan ini merupakan cikal bakal Kota Tangerang. Namun saat ini komunitas yang relatif masih asli hanya terdapat di Kampung Sewan.

Sebagian besar masyarakat Cina Benteng hidup sederhana sebagai petani, peternak, nelayan, bahkan tukang becak. Cina Benteng memang selalu diidentifikasi dengan stereotip orang Tionghoa berkulit gelap, jago bela diri dan hidup sederhana (wawancara dengan Oey Tjin Eng, 23 Februari 2014).

Keunikan lainnya dari masyarakat Cina Benteng adalah bahwa mereka sudah berakulturasi dan beradaptasi dengan lingkungan dan kebudayaan lokal. Mereka tidak bisa lagi berbahasa Cina, sehari-hari mereka menggunakan bahasa Sunda dan Betawi. Fenomena Cina Benteng merupakan bukti nyata betapa harmonisnya kebudayaan Cina dengan kebudayaan lokal. Namun demikian masyarakat Cina Benteng masih mempertahankan dan melestarikan adat istiadat nenek moyang mereka yang sudah ratusan tahun.

Dari sejumlah sumber tertulis mengenai Cina Benteng terdapat beberapa buku yang dapat djadikan sumber acuan yang saling melengkapi. Buku pertama adalah "Sejarah Kabupaten Tangerang" karya Tim Pusat Studi Sunda dengan ketuanya Edi S Ekadjati yang dikeluarkan oleh Pemkab Tangerang pada tahun 2004. Buku ini membahas sejarah Kabupaten Tangerang dari masa prasejarah hingga reformasi. Selain itu juga terdapat 
beberapa lampiran seperti peta Tangerang

masa kolonial, dan table-tabel kependudukan.

Sumber tertulis kedua adalah skripsi yang berjudul "Kerusuhan Anti Cina di Tangerang Tahun 1946" karya Sinta Agustin. Skripsi ini membahas mengenai masyarakat Cina di Tangerang, dan latar belakang terjadinya anti Cina yang menyebabkan terjadinya kerusuhan. Sumber ketiga adalah hasil penelitian dari Lina Herlinawati mengenai Arsitektur Tradisional Cina pada Hunian Masyarakat Cina Benteng di Kabupaten Tangerang yang membahas tentang kebudayaan masyarakat Cina Benteng dan kesenian tradisionalnya. Selanjutnya adalah skripsi dari Yeni Sulistiani berjudul "Kehidupan Sosial-ekonomi masyarakat Cina Benteng di Tangerang pada Masa Orde Baru” yang membahas mengenai kondisi ekonomi masyarakat Cina Benteng dan hubungan interaksi masyarakat Cina Benteng dan masyarakat lokal.

Selama ini Tangerang dikenal sebagai kota industri yang penuh polusi, pusat manufaktur dan industri di Pulau Jawa dan memiliki lebih dari 1000 pabrik. Banyak perusahaan internasional yang memiliki pabrik di kota ini, tetapi banyak yang tidak tahu bahwa Tangerang adalah salah satu basis tempat tinggal warga keturunan Tionghoa terbesar di Indonesia.

Permasalahan yang muncul dalam penelitian ini adalah bagaimana kondisi sosial-budaya masyarakat Cina Benteng pada masa kolonial sampai masa kemerdekaan, kemudian apakah mereka juga tetap mempertahankan tradisi leluhurnya. Sebagai masyarakat minoritas di Indonesia, masyarakat Tionghoa memiliki masalah-masalah yang terus berkelanjutan tanpa ada jalan keluarnya. Adapun tujuan dari penelitian ini adalah mendeskripsikan secara singkat mengenai keadaan sosial-budaya masyarakat Cina Benteng di Tangerang dengan harapan dapat memperoleh gambaran tentang kehidupan mereka saat ini dengan latar belakang masa lalu.

\section{B. METODE PENELITIAN}

Penelitian ini menggunakan metode sejarah yang meliputi empat tahap: heuristik, kritik, interpretasi, dan historiografi. Heuristik yaitu tahap mencari dan menemukan sumber, baik sumber primer maupun sekunder. Untuk mendapatkan sumber tersebut peneliti langsung ke lapangan mendatangi instansi terkait yaitu Dinas Kebudayaan dan Pariwisata Kota Tangerang, Perpustakaan Daerah Kota Tangerang, Badan Pusat Statistik dan lain-lain. Selain itu dilakukan wawancara dengan tokoh/budayawan Cina Benteng Bapak Oey Tjin Eng dan Pemilik Museum Benteng Heritage Bapak Udaya Halim. Langkah berikutnya adalah melakukan kritik sumber untuk mengetahui apakah sumber-sumber tersebut valid dan dapat dipercaya. Sumber-sumber dikritik baik ekstern maupun intern. Langkah berikutnya adalah interpretasi, merupakan tahap menafsirkan fakta-fakta yang telah terkumpul dengan mengolah fakta yang telah dikritisi dengan merujuk beberapa referensi. Terakhir adalah historiografi yang bertujuan untuk merangkaikan fakta-fakta tersebut menjadi tulisan sejarah.

\section{HASIL DAN BAHASAN}

\section{Gambaran Umum Kota Tangerang}

Kota Tangerang terletak di bagian utara Provinsi Jawa Barat, tepatnya di sebelah barat Kota Jakarta. Wilayah ini sekarang bukan lagi bagian dari Provinsi Jawa Barat karena sejak tahun 1999 ketika Banten memisahkan diri dari Jawa Barat dan menjadi Provinsi Banten, Tangerang menjadi salah satu bagian wilayahnya. Kota Tangerang terbagi atas 13 kecamatan, yaitu Kecamatan Batu Ceper, Kecamatan Benda, Kecamatan Cibodas, Kecamatan Ciledug, Kecamatan, Cipondoh, Kecamatan Jatiuwung, Kecamatan Karang Tengah, Kecamatan Karawaci, Kecamatan Larangan, Kecamatan Neglasari, Kecamatan Periuk, Kecamatan Pinang, dan Kecamatan Tangerang. 
Secara administratif Kota Tangerang berbatasan dengan: sebelah utara berbatasan dengan Kecamatan Teluk Naga dan Kecamatan Sepatan Kabupaten Tangerang; sebelah selatan berbatasan dengan Kecamatan Curug, Kecamatan Serpong, dan Kecamatan Pondok Aren, Kota Tangertang Selatan; sebelah timur berbatasan dengan DKI Jakarta, dan sebelah barat berbatasan dengan Kecamatan Pasar Kemis dan Cikupa, Kabupaten Tangerang.

Secara geografis Kota Tangerang memiliki letak yang strategis, karena berbatasan dengan DKI Jakarta dan Kota Tangerang Selatan serta Kabupaten Tangerang. Di samping itu Kota Tangerang juga merupakan salah satu daerah penyangga ibu kota negara DKI Jakarta dan merupakan kota terbesar di Provinsi Banten serta ketiga terbesar di kawasan perkotaan Jabotabek setelah Jakarta.

Pertengahan tahun 1882 pemerintah kolonial menetapkan batas Kota Tangerang sebaga ibu kota afdeling. Berdasarkan keputusan Gubernur Jenderal tanggal 25 Juni 1882, nomor 12 dan 13, batas Kota Tangerang ditetapkan sebagai berikut:

Sebelah utara: batas Kampung Benteng Makasar pada penyeberangan di Sungai Cisadane, Pasar Baru terus ke tembok rumah (gardu) pengawas (dekat Jalan Raya Pos yang menuju Jakarta) sampai perbatasan daerah Distrik Tangerang Timur.

Sebelah timur: batas antara tanah Distrik Tangerang Timur dan tanah pemerintah, jalan pedati di bagian timur Kampung Babakan pada persimpangan jalan menuju Serpong. Sebelah selatan: pabrik gula di Kampung Babakan sampai persimpangan jalan pedati. Sebelah barat: Sungai Cisadane pada penyebrangan ke Pasar Baru sampai pabrik gula di Kampung Babakan Utara (Ekadjati, 2004:104)

Tangerang disebut juga sebagai Batavia Barat yang berada di bawah pemerintahan seorang asisten residen berkebangsaan Belanda. Tangerang memiliki status sebagai Afdeling Tangerang. Afdeling merupakan wilayah administratif di bawah keresidenan (Halim, 2005: 4).

Distrik-distrik di Afdeling Tangerang mengalami banyak perubahan pada tahun 1880-an dan 1890-an. Pada mulanya Afdeling Tangerang terdiri atas 3 distrik, yaitu Distrik Tangerang Selatan, Distrik Tangerang Timur dan Distrik Tangerang Utara kemudian berubah jadi 4 distrik dengan ditambah Distrik Curug (Ekadjati, 2004: 105).

$\begin{array}{lrr}\text { Sejalan } & \text { dengan } & \text { perubahan } \\ \text { kebijakan } & \text { pemerintah } & \text { tentang }\end{array}$ pemerintahan dari sentralisasi ke arah desentralisasi pada tahun 1903 dan kemudian ke bentuk otonomi daerah pada 1922, status Tangerang berubah lagi dari afdeling kembali menjadi distrik di lingkungan Afdeling Batavia (Halim, 2005: 5).

Pada tahun 1985 Kota Tangerang masih termasuk dalam daerah administratif Pemerintahan di Kabupaten Tangerang yang terdiri atas satu kota administratif (kotif), 5 kewedanaan, 21 kecamatan, 5 kemantren, 20 kelurahan, dan 340 desa. Yang berstatus sebagai kota administratif (persiapan menuju kotamadya) adalah Kota Administratif Tangerang yang dibentuk berdasarkan Peraturan Pemerintah (PP) Nomor 50 Tahun 1981 tanggal 23 Desember 1981 dan diresmikan tanggal 19 Februari 1982. Daerah Kotif Tangerang ketika itu hanya mencakup 5 kecamatan, yaitu kecamatan: Tangerang, Batu Ceper, Cipondoh, Ciledug, dan Jatiuwung, yang dikepalai oleh seorang walikota administratif.

Semula luas daerah Kabupaten Tangerang adalah 128.281 hektar atau sekitar $1.283 \mathrm{~km}^{2}$. Luas wilayah tersebut mengalami pengurangan dengan terbentuknya Kotamadya Tangerang pada tanggal 28 Februari tahun 1993 (UU No. 2 th 1993) yang secara administratif pemerintahan berdiri sendiri dan statusnya sama. Dengan demikian, luas wilayah Kota 
Tangerang ialah $183,78 \mathrm{~km}^{2}$. Sebutan 'kotamadya' kemudian diganti dengan 'kota' pada tahun 2003.

Kepadatan penduduk di Kota Tangerang cenderung meningkat selama periode tahun 2000-2007. Selama tahun 2003 menurut data P4B tercatat 1.466.577 jiwa dengan jumlah kepala keluarga 368.858. Dengan demikian rata-rata jumlah anggota setiap rumah tangga adalah sebanyak 3,96 jiwa. Pada tahun 2007 jumlah penduduk mencapai 1.574.140 jiwa (BPS Kota Tangerang, 2007: xvi).

\section{Latar B elakang Kedatangan O rang Cina ke Tangerang}

Mengenai kedatangan orang Cina ke Tangerang memang masih belum diketahui secara pasti. Tetapi dalam kitab sejarah Sunda yang berjudul Tina Layang Parahyang (Catatan dari Parahyangan), yang telah diterjemahkan oleh Soedjarwo dari bahasa Sunda kuno ke dalam bahasa Latin, disebutkan tentang kedatangan orang Cina ke daerah Tangerang. Dalam kitab tersebut diceritakan tentang mendaratnya rombongan kapal yang dipimpin oleh Tjen Tjie Lung atau Halung sekitar tahun 1407 di muara Sungai Cisadane yang sekarang diberi nama Teluk Naga, tepatnya di Kampung Melayu. Pada saat itu pusat pemerintahan ada di Tegal Luar (daerah Tanah Tinggi) yang diperintah oleh Sanghyang Anggalarang sebagai wakil dari Sanghyang Banyak Citra dari sebuah kerajaan di wilayah Parahyangan (wawancara dengan Bapak Oey Tjin Eng, 23 Februari 2014).

Kapal rombongan Halung terdampar karena mengalami kerusakan serta kehabisan perbekalan. Tujuan mereka pada awalnya adalah Jayakarta (Jakarta). Kepergian mereka dari tanah leluhurnya disebabkan pada masa itu peperangan tengah berkecamuk tiada henti, oleh karenanya pencarian penghidupan yang lebih layak kerap dilakukan.

Sebagai bukti mengenai kehidupan awal masyarakat pribumi dan adanya sejumlah orang Tionghoa sebelum Masehi hingga awal Masehi adalah dengan adanya beberapa penemuan peninggalan di Situs Serpong, Situs Rawa Kidang, Situs Sugri, dan Situs Kramat Tangerang. Di situs-situs tersebut ditemukan tulang belulang, kapak perunggu yang tergolong Kebudayaan Dongson, gerabah, peti batu, mangkok dan piring buatan Cina (Sulistiyani, 2011: 82).

Rombongan Halung sedikitnya membawa tujuh kepala keluarga atau membawa sekitar 100 orang berada di kapal karam itu. Mereka kemudian menghadap Sanghyang Anggalarang untuk meminta pertolongan. Di dalam rombongan juga terdapat sembilan orang gadis dan anak-anak kecil. Kesembilan orang gadis tersebut memiliki paras cantik. Oleh karena kecantikannya pula mereka telah mampu membuat para pengawal Anggalarang jatuh cinta dan akhirnya kesembilan gadis itu dipersunting mereka. Sebagai kompensasinya, rombongan Halung diberi sebidang tanah di pantai utara Jawa sebelah timur Sungai Cisadane, yang sekarang disebut Kampung Teluk Naga. Selain kesembilan gadis tersebut sebagian lelaki dari negeri tirai bambu tersebut banyak yang menikahi gadis setempat karena pada umumnya mereka datang jarang yang membawa istri. Baru setelah tahun 1850 ketika kehidupannya telah mapan mereka pulang ke kampung halaman untuk mengajak kerabat dan keluarga bagi yang telah menikah (http://agemautau.blogspot.com/2010/01/se jarah-singkat-cina-benteng-3150).

Gelombang kedua kedatangan orang Tionghoa di Tangerang diperkirakan tahun 1740. Saat itu terjadi pemberontakan oleh orang Tionghoa karena keputusan Gubernur Jenderal Valkenier untuk menangkap orang-orang Tionghoa yang dicurigai. Pemberontakan masyarakat Tionghoa pada tahun 1740 menyebabkan pembantaian sekitar 10.000 orang Tionghoa tak berdosa oleh VOC dan pembakaran rumah-rumah mereka. Banyak di antara orang-orang Tionghoa pergi menyelamatkan diri ke Tangerang dan sekitarnya. VOC kemudian mengirimkan 
sisa-sisa orang Tionghoa ke Tangerang untuk bertani. Belanda mendirikan pemukiman bagi Orang Tionghoa berupa pondok-pondok yang sampai sekarang masih dikenal dengan nama Pondok Aren, Pondok Cabe dan sebagainya. Di sekitar Tegal Pasir atau Kali Pasir, Belanda mendirikan perkampungan Tionghoa yang dikenal dengan nama Petak Sembilan. Petak Sembilan merupakan salah satu cikal bakal Kota Tangerang, yaitu suatu tempat yang dihuni oleh komunitas Tionghoa. Perkampungan ini kemudian berkembang menjadi pusat perdagangan dan menjadi bagian dari Kota Tangerang, kawasan Pasar Lama sekarang, sebagai pemukiman pertama bagi komunitas Tionghoa di Tangerang

Kemudian orang-orang Tionghoa di tempat ini membangun Kelenteng Boen Tek Bio $($ Boen $=$ Sastra, Tek $=$ Kebajikan, Bio = tempat ibadah) pada tahun 1684, dan merupakan bangunan paling tua di Tangerang saat ini.

Pada akhir tahun 1800 sejumlah orang Tionghoa dipindahkan ke kawasan Pasar Baru, Tangerang dan sejak itu mulai menyebar ke daerah lain seperti Mauk, Serpong, Cisoka, Legok, bahkan sampai Parung di daerah Bogor. Itulah sebabnya banyak orang Tionghoa yang tinggal di pedesaan pelosok Tangerang. Disebutkan pula bahwa Pasar Baru tempo dulu merupakan tempat transaksi orang-orang Tionghoa yang datang lewat sungai dengan penduduk lokal. Di sini juga dibangun Kelenteng Boen San Bio (Nimmala) yang berselisih lima tahun dengan Boen Tek Bio yaitu tahun 1869 (wawancara dengan Bapak Udaya Halim, 24 Februari 2011).

\section{Masyarakat Cina Benteng di Kota Tangerang}

Semenjak dasawarsa kedua 1600an antara Banten dan Batavia terjadi persaingan perdagangan. Di satu pihak, Kompeni Belanda mempunyai keinginan untuk melakukan monopoli perdagangan di wilayah Kesultanan Banten. Namun di pihak lain, Sultan Banten sendiri mempertahankan sistem perdagangan bebas dan kedaulatan negara. Karena kerasnya persaingan itu, akhirnya berkembang menjadi konflik politik dan konflik senjata. Pada tahun 1652, konflik yang terjadi masih sebatas konflik senjata secara tertutup, namun kemudian pada tahun 1659 konflik berubah menjadi perang terbuka. Dalam suasana konflik tersebut, kawasan Tangerang menjadi daerah pertahanan sekaligus medan pertempuran serta rebutan antara Banten dan Batavia.

Dalam masa perkembangan berikutnya, pihak Banten membangun benteng pertahanan di sebelah barat Sungai Cisadane dan pihak Kompeni Belanda membangun benteng pertahanan di sebelah timur Sungai Cisadane. Oleh karena itu, dulu daerah ini dikenal dengan nama "Benteng", baru kemudian muncul nama Tangerang. Dengan mengerahkan serdadu Kompeni secara besar-besaran, terutama serdadu sewaan yang berasal dari kalangan orang Nusantara sendiri, dan taktik adu-domba (devide et impera), secara bertahap wilayah Kesultanan Banten jatuh ke tangan kekuasaan Kompeni Belanda. Awalnya, pada tahun 1569, daerah sebelah timur Sungai Cisadane jatuh ke tangan Kompeni. Kemudian tanah di sepanjang Sungai Cisadane sejak dari daerah hulu sampai ke muara dan daerah sebelah selatan Sungai Cisadane sampai ke Laut Kidul (Samudra Hindia) ditetapkan masuk ke wilayah Batavia pada tahun 1684.

Akhirnya pada tahun 1809 Kesultanan Banten dihapuskan. Seluruh wilayahnya dimasukkan ke wilayah pemerintahan Hindia Belanda. Sejak saat itu, berakhirlah kedudukan Tangerang sebagai daerah tapal batas antara Banten dan Jakarta, karena seluruhnya berada di bawah kuasa Pemerintah Kolonial Hindia Belanda. Perubahan pemegang kekuasaan atas daerah Tangerang memberikan jalan bagi perubahan status daerah itu. Semula berstatus sebagai daerah rebutan antara Banten dan Batavia, Tangerang kemudian 
menjadi daerah partikelir di bawah Batavia. Sepetak demi sepetak tanah di Tangerang dikuasai oleh pihak partikelir secara perseorangan dan perusahaan.

Sejak saat itu muncul sejumlah tuan tanah di daerah ini yang umumnya terdiri atas orang Belanda dan orang Tionghoa. Di samping menguasai tanah garapan dan lingkungannya, mereka juga menguasai penduduk yang bermukim di lahan itu. Penduduk setempat berkewajiban menggarap tanah milik tuan tanah dengan upah kecil, padahal mereka pun harus membayar berbagai pajak dan pungutan lainnya. Akibat kebijakan tersebut yang terjadi kemudian adalah adanya perbedaan yang sangat mencolok antara tingkat kesejahteraan tuan tanah dan tingkat kesejahteraan penduduk pribumi. Selain itu, tuan tanah lebih berkuasa daripada pejabat pemerintahan pribumi. Tuan tanah dilindungi dan dibantu oleh sejumlah mandor yang bertindak sebagai jawara dan berstatus sebagai pegawai tuan tanah. Keberadaan dan fungsi jawara dalam masyarakat Tangerang masa itu menjadi gejala umum dan ciri khas lingkungan tanah partikelir. Situasi dan kondisi demikian membentuk struktur dan karakter masyarakat tersendiri di lingkungan tanah partikelir.

Pendidikan sekolah hampir tak tersentuh oleh sebagian terbesar penduduk pribumi. Mereka belajar secara informal dari guru agama Islam secara individual, atau di pesantren-pesantren. Peran dan kedudukan orang keturunan Tionghoa dan jawara dalam masyarakat Tangerang sangat berpengaruh besar. Pemerintah kolonial Belanda telah mencatat banyaknya tanah partikelir di kawasan Tangerang yang dikuasai oleh orang Tionghoa. Bahkan hingga tahun 1940-an, tanah milik para tuan tanah Tionghoa masih tak terhitung jumlahnya di sana (Herlinawati, 2003:13).

Di Kota Tangerang ada satu komunitas warga Tionghoa yang disebut dengan "Cina Benteng". Istilah Cina Benteng muncul tidak terlepas dari berdirinya benteng Makasar yang membentang dari Pakulonan sampai ke Tangerang yang terletak di tepi Sungai Cisadane. Benteng Makasar dibangun pada masa Kolonial Belanda dengan tujuan sebagai garis pertahanan dari serangan orang-orang Banten ke Tangerang yang hendak ke Batavia (Ekadjati, 2004: 93). Tetapi sayang, tidak disebutkan tahun berapa benteng didirikan. Pada saat itu banyak orang Tionghoa yang kurang mampu tinggal di luar Benteng Makasar dan terkonsentrasi di sebelah utara, yaitu Sewan dan Kampung Melayu. Mereka telah tinggal di sana sejak tahun 1700-an. Akan halnya sebutan "Cina Benteng" untuk orang Indonesia keturunan etnik Tionghoa di Tangerang diberikan oleh masyarakat di luar Tangerang, terutama untuk mereka yang telah ada sejak zaman VOC (David Kwa, 2002: 16). Sebutan Cina ternyata berawal dari ucapan orang Eropa, diambil dari nama Dinasti Qin (baca: Chin, 225-206 SM).

Meskipun orang luar menyeragamkan sebutan "Cina Benteng" untuk etnis Tionghoa di Tangerang, di kalangan mereka sendiri dikenal dua istilah, "Benteng" dan "Udik". Sebutan "Benteng" mengacu untuk kawasan kota, sementara daerah luar kota disebut "Udik". Orang Cina Benteng juga mengidentifikasi diri sebagai "orang Cina", sedangkan etnis Melayu atau Sunda di sekitar mereka disebut "orang kampung". Namun hubungan antaretnis ini sangat baik. Istilah "orang kampung" sendiri dimaksudkan sebagai orang yang punya kampung, sama sekali tidak mengandung maksud peyoratif. Sampai saat ini masyarakat Cina Benteng telah membaur dengan warga lokal secara harmonis sehingga memberi warna baru dalam kehidupan masyarakat (David Kwa, 2002: 18).

Secara fisik memang sulit membedakan antara Cina Benteng dan "orang kampung", tetapi upaya mempertahankan identitas budaya etnik masih tetap tampak. Sebutan "orang Cina" atau "orang Kampung" memang lebih 
bersifat kultural dibandingkan fisik. Label Cina Benteng mereka sandang sebagai identitas kultural yang membedakan mereka dengan kelompok etnis Tionghoa lainnya di Indonesia.

Apabila diperhatikan lebih dalam sebenarnya terdapat perbedaan antara Cina Benteng dan Cina peranakan pada umumnya. Cina Benteng bukan hanya peranakan dalam arti biologis, tetapi juga dalam kebudayaan. Dalam kehidupan sehari-hari, mereka menggunakan bahasa Sunda dan Betawi. Kebanyakan dari mereka tidak dapat berbahasa Tionghoa. Adat istiadat mereka juga tidak 100\% Tionghoa, tetapi mereka telah mengambil adat istiadat penduduk pribumi (Onghokham, 2009: 29). Cina Benteng merupakan bagian dari kaum pribumi Tangerang karena di situlah kampung halaman mereka.

\section{Kehidupan Sosial-Budaya Masyarakat Cina Benteng}

Pada masa Pemerintah Hindia Belanda penduduk Nusantara dibagi menjadi tiga golongan menurut stratifikasi ras yang ada di Nusantara, yaitu:

1. Golongan Eropa menempati stratifikasi sosial tertinggi, contohnya orang Belanda, Portugis, dan Inggris.

2. Golongan Timur Asing, contohnya orang Tionghoa, Arab, dan India.

3. Golongan Bumiputera atau pribumi (Lohanda, 2001: 2).

Pembagian golongan tersebut sebenarnya refleksi politik divide et impera Pemerintah Hindia Belanda. Dengan pembagian golongan tersebut tentu saja menimbulkan prasangka-prasangka rasialis dalam masyarakat pribumi. Orang Tionghoa ditempatkan di posisi kedua di atas golongan pribumi padahal mereka bukan penduduk asli. Urutan yang lebih tinggi dari pribumi dalam stratifikasi sosial membuat orang-orang Tionghoa tertentu merasa lebih superior dibandingkan dengan masyarakat pribumi, bahkan sering menganggap rendah orang pribumi (Agustin, 2011: 40).
Sejak tahun 1843 orang Tionghoa dijadikan sebagai partner oleh orang Belanda. Mereka diberi hak untuk menarik pajak dari pribumi. Dengan diberikannya kesempatan tersebut, mereka melakukan praktik pemerasan terhadap pribumi (Hidayat, 1993: 143). Mereka memiliki kontribusi besar terhadap kelangsungan kekuasaan kolonial Belanda di Tangerang. Banyak dari orang Cina Benteng yang diangkat menjadi kapiten Tionghoa pada era feodalisme tuan tanah di Tangerang. Mereka sangat loyal terhadap Belanda. Kehidupan sosial masyarakat Cina Benteng sempat mengalami kemakmuran pada masa Pemerintahan Hindia Belanda, karena sebagian etnis Tionghoa merupakan partner Belanda dalam bidang perdagangan.

Di sisi lain sebenarnya pada masa Pemerintahan Hindia Belanda, etnis Tionghoa juga diperlakukan secara diskriminatif, walaupun ada segelintir orang Tionghoa yang dijadikan mesin pencetak uang oleh Pemerintah Kolonial Belanda. Merekalah yang selalu dianggap seolah-olah seluruh etnis Tionghoa menjadi antek-antek Belanda. Beberapa contoh pendiskriminasian pada zaman Hindia Belanda ialah bahwa orang Tionghoa tidak diizinkan menjadi pegawai negeri, tidak bisa membeli tanah, harus tinggal di daerah Chinese Wijk atau Pecinan. Belanda juga tidak mengurus pendidikan dan kesehatan orang Tionghoa (Sulistiyani, 2011: 84).

Tetapi kemudian kehidupan sosial masyarakat Cina Benteng yang makmur mengalami perubahan ketika masa awal kemerdekaan Republik Indonesia, pada saat Belanda menyerahkan kekuasaannya kepada Republik Indonesia. Bahkan mereka kemudian hidup di bawah garis kemiskinan. Orang-orang Cina Benteng tentunya merasa sangat kehilangan ketika Belanda meninggalkan Tangerang pada tahun 50-an.

Perpindahan kekuasaan tersebut mengakibatkan beberapa masyarakat beranggapan bahwa etnis Tionghoa adalah 
tangan kanan Belanda. Bahkan sempat terjadi kerusuhan anti Cina di mana pribumi melakukan penyerangan dan perampasan terhadap etnis Tionghoa Tangerang pada tahun 1946. Banyak di antara mereka yang dulunya kaya kemudian menjadi miskin karena harta leluhur mereka telah dirampas. Saat itulah hubungan Cina Benteng dengan pribumi mengalami kemunduran paling ekstrem, karena pribumi menuduh masyarakat Tionghoa berpihak ke Belanda.

$$
\text { Dalam bidang pendidikan }
$$

masyarakat Cina Benteng saat itu tidak dapat menempuh pendidikan formal ke jenjang yang lebih tinggi. Mereka sebagian hanya bisa duduk di bangku Sekolah Dasar (SD), selebihnya hampir tidak mengenyam pendidikan. Pendidikan yang rendah mengakibatkan masyarakat Cina Benteng hidup dalam kemiskinan dari generasi ke generasi. Karena itu orang Cina Benteng lebih memilih untuk bekerja sebagai buruh tani, tukang becak, nelayan dan sebagainya.

Mayoritas komunitas Cina Benteng berasal dari suku Hokkian yang umumnya bermata pencaharian petani, pedagang, nelayan, dan ahli perkebunan. Mereka telah turun temurun menjadi petani atau buruh tani dan tidak ada perbedaan yang mencolok dengan penduduk pribumi setempat karena pada umumnya mereka sama miskinnya.

Keunikan dari masyarakat Cina Benteng yaitu karena mereka memiliki budaya khas tersendiri yang berbeda dengan warga Tionghoa pada umumnya, mereka telah mampu berakulturasi dan beradaptasi dengan lingkungan dan kebudayaan lokal. Mereka tinggal di pedesaan yang telah berinteraksi dan berasimilasi dengan penduduk pribumi sehingga fisik mereka sangat sukar dibedakan.

Hubungan interaksi masyarakat Cina Benteng dengan masyarakat lokal di Tangerang juga menimbulkan penetrasi kebudayaan yaitu masuknya pengaruh suatu kebudayaan ke kebudayaan lainnya.
Penetrasi kebudayaan bisa melalui dua cara, yaitu penetrasi damai dan penetrasi kekerasan. Penetrasi kebudayaan antara masyarakat Cina Benteng dengan masyarakat lokal di Tangerang terjadi melalui proses penetrasi damai.

Perkawinan campuran antara lakilaki Tionghoa dan wanita pribumi atau sebaliknya di Tangerang telah berlangsung lama, sejak ratusan tahun yang lalu yaitu sejak datangnya rombongan Halung ke Teluk Naga.

Tradisi perkawinan yang terjadi akibat adanya integrasi etnis Cina Benteng dengan masyarakat lokal disebut dengan Chiou-Thaou. Acara pernikahan ChiouThaou diselenggarakan dalam tradisi kuno masyarakat Cina Benteng dan merupakan upacara pernikahan yang unik dan langka. Masyarakat Tionghoa Tangerang dapat dikatagorikan hampir seluruhnya merupakan Tionghoa peranakan

Tetapi meskipun mereka mampu berakulturasi dan beradaptasi dengan penduduk, masyarakat Cina Benteng masih tetap mempertahankan dan melestarikan adat istiadat nenek moyang mereka yang sudah ratusan tahun. Cina Benteng merupakan komunitas masyarakat Tionghoa yang masih kuat memegang teguh tradisi leluhurnya. Selain itu, terlihat pula dari rumah-rumah mereka terdapat pemujaan arwah leluhur berupa meja abu yang biasanya ditempatkan di ruang depan rumah. Selain meja abu di rumah mereka selalu ada penempelan secarik kertas kuning bertuliskan aksara Cina di depan pintu masuk yang disebut hoe, berfungsi sebagai penjaga keselamatan, keberuntungan, dan penolak bala.

Sejarah Cina Benteng tidak bisa dipisahkan dengan kawasan Pasar Lama, yaitu Jalan Ki Samaun dan sekitarnya yang berada di tepi sungai dan merupakan pemukiman pertama masyarakat Cina di sana. Struktur tata ruangnya sangat baik dan itu merupakan cikal-bakal Kota Tangerang. Mereka tinggal di tiga gang, yang sekarang dikenal sebagai Gang 
Kalipasir, Gang Tengah (Cirarab), dan Gang Gula (Cilangkap).

Beberapa tradisi leluhur yang masih dipertahankan antara lain Cap Go Meh (perayaan 15 hari setelah Imlek), Pek Cun, Tiong Ciu Pia (kue bulan), dan Pek Gwee Cap Go (hari kesempurnaan). Demikian pula panggilan encek, encim, dan engkong masih digunakan sebagai tanda hormat kepada orang yang lebih tua. Juga salam (pai) tetap dipertahankan dalam keluarga Cina Benteng pada saat bertemu dengan orang lain. Yang khas dari masyarakat Cina Benteng adalah pakaian pengantin yang merupakan perpaduan antara budaya Cina dan Betawi. Pakaian pengantin laki-laki merupakan pakaian kebesaran Dinasti Ching, seperti terlihat dari topinya, sedangkan pakaian pengantin perempuan hasil akulturasi Cina-Betawi yang tampak pada kembang goyang.

Fenomena Cina Benteng adalah bukti nyata betapa harmonisnya kebudayaan Tionghoa dengan kebudayaan lokal. Lebih dari itu, keberadaan Cina Benteng seakan menegaskan bahwa tidak semua orang Tionghoa memiliki posisi kuat dalam bidang ekonomi. Dengan keluguannya, mereka bahkan tak punya akses politik yang mendukung posisinya di bidang ekonomi. Fenomena Cina Benteng adalah contoh dan bukti nyata proses pembauran yang terjadi secara alamiah. Masyarakat Cina Benteng hampir tidak pernah mengalami friksi dengan etnis lainnya (Sulistiyani, 2011: 3). Realitas Cina Benteng yang tinggal di pusat kekuasaan politik dan ekonomi menunjukkan, masyarakat etnis Cina sesungguhnya sama dengan etnis lainnya. Ada yang punya banyak uang, tetapi ada pula yang hidup di bawah garis kemiskinan.

\section{a. Kesenian}

Dalam perkembangan kesenian pada masyarakat Cina Benteng terjadi akulturasi budaya antara etnis Tionghoa dan penduduk pribumi. Akulturasi tersebut menghasilkan kebudayaan baru tanpa menghilangkan kebudayaan aslinya.

Kesenian masyarakat Cina Benteng yang telah berakulturasi dengan masyarakat pribumi, salah satunya adalah Gambang kromong dan tari Cokek. Gambang kromong adalah musik pengiring pertunjukan lenong. Dari instrumen musik dan jenis lagu-lagunya terasa kuat pengaruh Tionghoa. Gambang kromong bisa dimainkan sendiri tanpa harus mengiringi lenong. Perlengkapan musik gambang keromong dari namanya saja menunjukkan membaurnya unsur-unsur Tionghoa, Melayu, Sunda, dan Jawa. Pengaruh Tionghoa bisa dilihat dari tiga macam biola yang diberi nama tehyan, kengahyan, dan shukong. Sedangkan gambang kromong, kecrek, dan gong bisa disebut sebagai alat-alat gamelan yang mewakili budaya Sunda dan Jawa (Setiono, 2008: 594).

Tari Cokek adalah tarian khas Tangerang yang diwarnai budaya etnik Tionghoa. Tarian ini diiringi orkes gambang kromong ala Betawi dengan penari mengenakan kebaya yang disebut cokek. Cokek merupakan tradisi lokal masyarakat Betawi dan Cina Benteng. Tarian cokek mirip tari sintren dari Cirebon atau sejenis tari ronggeng.

Hubungan interaksi yang terjadi pada masyarakat Cina Benteng dengan masyarakat lokal di Tangerang tidak hanya terbentuk karena adanya proses akulturasi kebudayaan, tetapi juga terjalin pada saat melaksanakan upacara keagamaan.

\section{b. U pacara yang Berkaitan dengan Daur Hidup \\ 1. U pacara Perkawinan Ciotau}

Upacara ciotau merupakan upacara asli dari negara Tiongkok lengkap dengan sesaji dan tata cara yang penuh simbolis. ciotau memiliki arti sumpah sehidup semati dan di akhirat akan bertemu lagi. Upacara ciotau dilakukan pada pagi hari sekitar pukul lima pagi, dimulai saat pengantin perempuan duduk di sebuah tampah besar yang tengahnya diberi 
bundaran berwarna merah mirip bendera Jepang, disusul oleh mempelai laki-laki. Tampah besar ini dilambangkan sebagai dunia yang berbentuk bulat dengan segala isinya. Malam harinya, pesta masih berlangsung dengan meriah dengan adanya hiburan kesenian gambang kromong. Setelah lewat tengah malam acara yang diselenggarakan 2 hari 2 malam ini pun selesai.

\section{Tradisi-tradisi Seputar Kelahiran}

Di kalangan warga Cina Benteng, kelahiran anak, terutama anak laki-laki, merupakan satu hal yang sangat menggembirakan karena akan menjadi penerus marganya (she). Tak heran, sejak anak masih dalam kandungan banyak pantangan yang tidak boleh dilanggar oleh sang ibu. Ibu yang hamil jika akan keluar rumah atau pergi jauh diharuskan membawa gunting kecil, peniti, jarum, pisau lipat, dan benda tajam lainnya. Hal ini dimaksudkan agar terhindar dari gangguan makhluk halus yang jahat. Pantangan lain adalah ibu hamil serta keluarganya tidak boleh membunuh atau menyiksa binatang, karena jika dilanggar maka anaknya akan cacat atau bahkan mati. Ketika sang ibu sudah melahirkan, maka keluarganya akan mengundang sanak saudara.

Saat anak sudah berumur satu tahun, biasanya diadakan suatu perayaan agar anak merasa gembira. Untuk mengetahui watak si anak kelak, orang tua melakukan satu upacara yakni anak disuruh memilih uang, pensil, mainan dan sebaginya. Dari situ terlihat watak anak bagaimana, misalnya jika anak memilih uang maka dia pintar berdagang, dan jika memilih pensil maka anak akan menjadi orang pandai dan lain sebagainya.

\section{Tradisi-tradisi Seputar Kematian}

Di dalam tradisi masyarakat Cina Benteng ketika ada salah satu keluarga meninggal dunia, keluarga yang ditinggalkan segera membeli hio-lo, yaitu tempat hio, salah satu perlengkapan untuk sembahyang. Di meja abu selain hio-lo disediakan juga sepasang pelita atau lampu. Sesudah jenazah dimandikan lalu diberi pakaian rapi dan hiasan. Sore hari, setelah semua keluarga berkumpul dan mayat akan dimasukkan ke dalam peti mati, dilakukan sembahyang jit-bok, yakni memaku peti ambil menyerukan kata-kata: It Tian teng Po Pi Kia Sai yang artinya dengan palu yang pertama ini semoga memberkahi anak cucu. Paku kedua ditancapkan dengan mengucapkan semoga keluarga yang ditinggalkan hidup makmur. Paku ketiga dan empat dipantekkan dengan diiringi ucapan semoga keluarga yang ditinggalkan hidup bahagia. Sementara itu sebagian orang sudah menyalakan kayu bakar dan membakar kertas, mereka terus membakar jangan sampai putus agar asapnya bisa mengantarkan sampai nirwana.

Pada masyarakat Cina Benteng jenazah disemayamkan di rumah sendiri (duka) sampai 3 hari. Selama 3 hari mereka melakukan sembahyangan dan hari terakhir melakukan upacara menggeser peti mati. Upacara ini disebut sembahyang ki hok yang biasanya diselenggarakan pada malan hari. Peti mati yang semula berada di tengah ruangan rumah, sekarang digeser ke tepi tembok ruangan. Pemindahan peti jenazah ini dianggap sangat penting, agar kedudukan peti sejajar dengan tembok rumah.

$\begin{array}{ccc}\text { Ketika } & \text { jenazah } & \text { sampai di } \\ \text { pekuburan, } & \text { meluarga } & \text { melakan }\end{array}$ sembahyang dengan membakar hio oleh pihak keluarga, kemudian dilanjutkan dengan para pelayat yang lain. Sesudah melakukan sembahyang, peti mati dimasukkan ke liang kubur dan ditimbun dengan tanah. Upacara berikutnya adalah penyebaran berbagai bibit seperti padi, jagung, dan uang logam. Menurut kepercayaan, bibit yang tumbuh dengan baik, penaburnya akan disayang oleh almarhum.

Pada hari ketujuh, diadakan sembahyang tujuh hari atau balik-to. Pada saat sembahyang biasanya disediakan 
rumah-rumahan dari kertas lengkap dengan patung mobil, peti uang, perabot rumah tangga dan lain sebagainya. Selesai sembahyang maka rumah-rumahan dari kertas itu dibakar bersama-sama dengan segala artibutnya. Lamanya berkabung bagi warga Cina Benteng cukup lama kurang lebih satu tahun. Selama berkabung tidak diperbolehkan memakai perhiasan dan pakaian berwarna, mereka hanya menggunakan pakaian warna hitam atau putih, tidak boleh menghadiri pesta atau mengadakan pesta.

\section{U pacara yang Berkaitan dengan Hari-hari Besar Agama}

Dibandingkan dengan masyarakat Tionghoa lainnya, masyarakat Cina Benteng masih melakukan upacara peringatan hari-hari besar agama secara lengkap. Ketaatan mereka pada tradisi leluhur, tercermin dari berbagai upacara yang masih dilakukan seperti perayaan tahun baru imlek yitu tahun baru penanggalan Cina, upacara ceng beng, upacara toan ngu/pec-hun, upacara cit gwe, peh gwe, cap gwe, cia gwe dan cap go meh.

\section{a. Tahun Baru Imlek (Sin-cia)}

Pesta tahun baru Imlek juga disebut sebagai pesta tahun baru musim semi. Masyarakat Cina Benteng merayakan dari tanggal 1 cia-gwe sampai tanggal 15 cia-gwe, yaitu pada saat dirayakan hari raya cap go meh. Menurut sejarah, tahun baru Imlek dirayakan karena adanya musim semi tiba, mereka saling mengucapkan selamat tahun baru semoga banyak rejeki, gong xi fat choy. Seperti diketahui, di Tiongkok musim terbagi dalam 4 musim yakni musim semi, gugur, panas, dan dingin. Masyarakat Cina Benteng merayakan tahun baru Imlek 15 hari penuh, berbeda dengan orang Tionghoa lainnya yang hanya merayakan 3 hari.

Tepat pukul 12 tengah malam di akhir bulan 12 imlek, masyarakat Cina Benteng tua, muda, besar, kecil secara bersama mengucapkan selamat tahun baru Imlek semoga selamat dan banyak rezeki. Saat sekarang pesta tahun baru imlek dimeriahkan dengan permainan barongsay, namun pada masyarakat Cina Benteng permainan yang diadakan adalah tanjidor yakni kesenian tradisional yang menggunakan alat terompet dan drum. Selain tanjidor, juga dimeriahkan dengan suara petasan dan kembang api.

Beberapa pantangan dalam pelaksanaan tahun baru imlek adalah mereka dilarang menyapu rumah, lantai dan membersihkan berbagai peralatan dapur. Konon katanya agar jangan sampai rezeki terusir atau tersapu keluar dari rumah. Pembersihan rumah dan peralatan dapur boleh dilakukan sehari atau beberapa hari menjelang perayaan tahun baru imlek. Larangan lain adalah tidak boleh makan nasi berkuah, agar tidak mengalami kehujanan di jalan pada saat mereka paicia, atau sowan ke rumah sanak famili. Mereka juga dilarang membuka toko sebelum 5 hari perayaan tahun baru imlek.

Tradisi perayaan tahun baru imlek di berbagai daerah cenderung tidak sama, tapi di Jawa Barat khususnya di Tangerang, yaitu masyarakat Cina Benteng ada satu makanan khas yang tidak ada di daerah lain yakni ikan bandeng. Ikan bandeng merupakan ikan yang harus ada di perayaan tahun baru Imlek, digunakan sebagai samseng atau sesaji untuk arwah para leluhur. Ikan bandeng selalu disajikan di atas meja abu sebagai persembahan untuk leluhur, di samping sesaji yang lain.

\section{b. Perayaan Cap Go M eh}

Perayaan cap go meh dilakukan tiap tanggal 15 Cia gwee atau hari terakhir perayaan Imlek. Pertama-tama, semua sesaji diturunkan dari meja abu leluhur. Kue keranjang yang ada dalam sesaji digoreng seperti layaknya pisang goreng. Kue keranjang dipotong tipis-tipis kemudian dicampur dengan tepung, telur, lada, garam, dan kapur sirih, lalu digoreng hingga renyah. 
Selain kue keranjang, ada yang lebih khas lagi yakni masakan lontong cap go meh. Lontong cap go meh merupakan makanan khas masyarakat Cina Benteng, khusus untuk merayakan hari cap go meh. Menurut informan, pada tanggal $14 \mathrm{Cia}$ gwee para ibu sibuk di dapur memasak lontong cap go meh. Bahan membuat lontong adalah daun dan beras. Pada perayaan cap go meh ini banyak warga Cina Benteng yang menghentikan semua kegiatan atau tidak melaksanakan kerja apa pun. Tanggal 15 Cia-gwee dianggap sebagai hari untuk membuang sial, oleh sebab itu mereka selalu berada di dalam rumah saja untuk menghindari bencana dan berbagai macam penyakit.

\section{c. Perayaan Kue $\mathbf{O}$ nde}

Bulan keenam imlek tepatnya tanggal 15 lak gwee, masyarakat Cina Benteng melakukan sembahyang kue onde atau sembahyang pertengahan tahun. Tujuan dari upacara ini adalah menyambut roh-roh orang yang sudah meninggal, terutama mereka yang tidak terurus oleh keluarganya atau tidak punya keluarga. Bagi warga Cina Benteng, upacara ini disebut upacara membuka pintu akherat. Di depan rumah diletakkan meja sembahyang yang di atasnya terdapat sepasang lilin merah, sebuah gelas untuk menancapkan hio, 3 piring kecil berisi manisan dan tiga cangkir teh. Selesai pasang hio mereka melakukan sembahyang dan membakar kertas bergambar baju, celana, rok, topi, sepatu dan lain sebagainya. Maksud dari upacara ini adalah agar para roh turun ke bumi untuk makan sedekah atau sesaji (sam seng) yang telah disediakan. Upacara ini disebut dengan sembahyang cio ko yakni sembahyang rebutan.

Upacara rebutan dilakukam pagi hari tanggal tanggal 29-30 lak gwee. Upacara rebutan pada masyarakat Cina Benteng dilakukan cukup meriah, yakni terdapat arak-arakan anak yang membawa bendera merah dari kain sutera. Di belakangnya terdapat rombongan orang tua thau ke yang membawa abu toa pe kong. Rombongan ini diiringi musik tetabuhan. Pada pukul 10 mereka sembahyang di kelenteng, usai sembahyang mereka mebakar siu kim (kertas kuning).

\section{d. Sembahyang Sin Beng}

Pada tanggal 15 peh gwee atau tanggal 15 bulan delapan imlek, masyarakat Cina Benteng melakukan sembahyang sin beng, yakni sembahyang untuk para arwah leluhur, atau di Indonesia dikenal dengan nama sembahyang kue tiong ciu phia (kue pia). Kue pia ini berbentuk bundar seperti bulan purnama dan di tengahnya terdapat gambar kelinci merah. Masyarakat Tionghoa meyakini bahwa di dalam rembulan itu ada seekor kelinci.

Sembahyang sin beng dilakukan di rumah dengan menyiapkan peralatan meja sembahyang, hio dan lilin merah. Jika pelaksanaannya sore hari dilakukan di luar rumah, dan bila dilakukan pagi hari dilaksanakan di dalam rumah. Sesaji yang disediakan adalah sam seng, manisan buah, rokok dan secangkir teh. Sesudah sembahyan dilakukan rebutan sesaji. Ini merupakan simbol para arwah leluhur yang sedang makan sesaji.

\section{e. U pacara Ceng Beng}

Masyarakat Cina Benteng juga melakukan upacara ceng beng yakni melakukan ziarah dan membersihkan makam para leluhur. Ceng beng artinya bersih dan terang. Pada saat perayaan ceng beng, mereka dianjurkan membersihkan makam leluhur. Upacara ceng beng biasa disebut juga dengan the-coa.

Perayaan ceng beng diperingati masyarakat Cina Benteng setiap tanggal 5 April, atau dalam penanggalan Cina adalah tanggal 3 Sha-gwee (bulan tiga Imlek). Pada saat itu mereka melakukan ziarah ke makam orang tua atau leluhurnya, sekaligus membersihkan makam. Tidak lupa mereka membawa makanan yang biasa disukai oleh almarhum di masa hidupnya. Setelah membersihkan makam, 
dilanjutkan dengan sembahyang hio. Selesai sembahyang mereka menikmati makanan bersama, sebagai penghormatan pada almarhum.

\section{f. Toan Ngo (Peh Cun)}

Upacara peh cun adalah upacara menghias perahu dan lomba perahu dayung naga. Peh cun berasal dari kata peh artinya dayung dan cun artinya perahu. Jadi peh cun memiliki arti lomba mendayung perahu. Peh cun dirayakan setiap tanggal 5 go gwee, yakni bulan kelima penanggalan Imlek. Pada masyarakat Cina Benteng lomba perahu dayung ini masih dilaksanakan sampai sekarang, meskipun di daerah lain sudah tidak dijumpai lagi. Pada masa Orde Baru kegiatan ini sempat dilarang, dan kemudian di masa Presiden Gus Dur diperbolehkan kembali.

Dalam perlombaan ini semua perahu dihias dengan kertas warna-wani. Warna yang dominan adalah warna merah yang dipandang sebagai lambang keberuntungan. Para pendayung membekali diri dengan makanan ki cang dan ba cang. Sebelum dimulai, kue ki cang dan ba cang dilempar ke dalam sungai di mana perlombaan akan dilakukan. Setelah itu dimulailah perlombaan perahu dengan diiringi tepukan dan teriakan para pendayung dan orang yang menonton. Bagi pemenang akan diberi hadiah sejumlah uang.

Hari raya peh cun diramaikan juga dengan berbagai atraksi seperti penabuh tambur, gembreng, dan membakar petasan, serta yang paling menarik adalah acara mendirikan telur yang waktunya tepat pada tengah hari. Perayaan ini berlangsung dari pagi hingga sore hari dan banyak orang yang minum arak serta mandi di sungai yang diyakini bisa menyembuhkan berbagai macam penyakit. Pada perayaan peh cun juga banyak masyarakat yang mencari obat mujarab dari tumbuhtumbuhan, air, atau apa saja yang dianggap mengandung khasiat tinggi untuk menyembuhkan penyakit. Menurut kepercayan para ahli obat Tionghoa, pada hari itu hawa bumi dan langit bertemu, sehingga sesuatu yang ada di bumi termasuk tumbuh-tumbuhan maupun air kemasukan hawa tersebut.

\section{PEN UTUP}

Apabila berbicara mengenai pembauran di Indonesia, masyarakat Cina Benteng di Kota Tangerang merupakan contoh wujud keberhasilan akulturasi atau pembauran di Indonesia. Keberadaan Cina Benteng di Tangerang membentuk perpaduan budaya bercorak IndonesiaTionghoa yang unik dan sarat makna. Secara ekonomi Cina Benteng adalah salah satu etnis Tionghoa yang bisa dikatakan miskin di Indonesia, mereka umumnya bekerja sebagai buruh, petani, nelayan, dan tukang. Secara sosial kelompok ini bisa menyatu dengan kaum pribumi, meski karena politik mereka mengalami kesenjangan sosial.

Dalam keseharian kelompok Cina Benteng memiliki keunikan di mana interaksi dan cara hidup sudah sangat mirip dengan kaum pribumi. Meski begitu menyerupai kaum pribumi, kelompok Cina Benteng tidak pernah menghilangkan beberapa tradisi leluhur seperti pada perayaan dan ritual-ritual. Pengaruh kehidupan masyarakat Cina Benteng yang utama adalah menyadarkan kaum Tionghoa dan pribumi melalui contoh keharmonisan yang sesungguhnya diharapkan oleh kedua belah pihak. Dengan melihat kisah Cina Benteng, maka anggapan negatif terhadap etnis Tionghoa dapat diredam, nilai-nilai positif yang mendidik dari Cina Benteng dapat diangkat. Kekukuhan masyarakat Cina Benteng dalam menjaga tradisi leluhur merupakan aktualisasi penghargaan, penghormatan, sekaligus ketakutan akan leluhur mereka yang diyakini selalu menjaga, melindungi, dan dekat dengan keseharian hidup mereka.

Namun saat ini, berabad kemudian setelah mereka berjuang dari titik awal keberadaan Kota Tangerng ada kejadian 
miris yang menimpa masyarakat Cina Benteng yang patut dijadikan bahan renungan untuk kita. Pada tahun 2010, Pemerintah Kota Tangerang merencanakan penggusuran terhadap 350 keluarga warga Kampung Neglasari di tepi Sungai Cisadane yang nota bene adalah masyarakat Cina Benteng yang merupakan salah satu unsur utama perintis dan pembentuk Kota Tangerang, yang memiliki hak ekonomi, sosial, dan budaya yang tidak bisa ditindas pemerintah kota. Rencana penggusuran itu menandakan bahwa pemerintah Kota Tangerang telah sangat melupakan faktor sejarah dari keberadaan masyarakat Cina Benteng. Sementara di sisi lain ada pihak yang terus berupaya melestarikan sejarah dengan menjadikan kawasan Pasar Lama sebagai museum hidup.

Masalah penggusuran pemukiman Cina Benteng tidak bisa dilihat hanya dengan modal payung hukum yang ada. Ada unsur warisan budaya yang harus diperhitungkan dalam mengambil keputusan. Bukankah pelestarian budaya juga memiliki payung hukum? Seandainya nilai budaya bisa dinilai dengan uang mungkin kita baru bisa melihat untung ruginya penggusuran paksa ini. Penataan kota penting tapi akan lebih bernilai bila penataan tersebut dilakukan dengan mempertahankan budaya setempat sehingga kota bukan hanya sekedar kumpulan bangunan yang tertata rapi.

Sudah seharusnya proses interaksi yang telah berlangsung ratusan tahun, sekaligus menggambarkan kekompakan dua budaya berbeda ini untuk tetap survive menghadapi tantangan zaman. Sebuah proses pertukaran budaya yang berlangsung alamiah tanpa paksaan dan tendensi macam-macam.

\section{UCAPAN TERIMA KASIH}

Penulis mengucapkan terima kasih kepada Bapak Oey Tjin Eng, selaku budayawan dan pengurus Klenteng Boen Tek Bio yang telah memberi informasi mengenai sejarah keberadaan masyarakat
Cina Benteng di Tangerang, Bapak Udaya Halim selaku budayawan dan pemilik Museum Benteng Heritage, Bapak Nurul Huda selaku Kabid budaya Disbudpar Kota Tangerang, dan semua pihak yang telah memberikan bantuan pada saat penelitian tersebut.

\section{DAFTAR SUMBER}

\section{Skripsi}

Agustin, Shinta. 2011. Kerusuhan Anti Cina di Tangerang Tahun 1946. Skripsi. Bandung: FASA UNPAD

\section{Buku}

BPS Kota Tangerang, 2007.

Tangerang; Pemda Kota Tangerang.

Ekadjati, Edi S. 2004.

Sejarah Kabupaten Tangerang, Cetakan ke I, Tangerang: Pemkab Tangerang .

Halim, Wahidin. 2005.

Ziarah Budaya Kota Tangerang; Menuju Masyarakat Berperadaban Akhlakul Karimah, Jakarta: Pendulum.

Herlinawati, Lina. 2003. Arsitektur Tradisional Cina pada Hunian Masyarakat Cina Benteng di Kabupaten Tangerang, Bandung: BKSNT Bandung.

Hidayat, Z.M. 1993. Masyarakat dan Kebudayaan Cina Indonesia. Bandung: Tarsito.

Kuntowijoyo. 1999.

Metodologi Sejarah, Yogyakarta: Tiara Wacana Yogya.

Lohanda, Mona. 2000.

Masalah Cina Benteng dalam Perjalanan Sejarah Indonesia. Jakarta: Pustaka Inspirasi

Onghokham, 1983. Rakyat dan Negara. Jakarta: Sinar Harapan. 
.2009 .

Riwayat Tionghoa Peranakan di Jawa, Jakarta: Komunitas Bambu.

Setiono, Benny G. 2008

Tionghoa dalam Pusaran Politik. Jakarta: Transmedia.

\section{Majalah}

David Kwa. 2002

"Cina Benteng di Republik Rakyat Tangerang", Intisari edisi khusus, Oktober 2002, hlm: 14

Lohanda, Mona. 2002

"Ketika Tionghoa dan Betawi berinteraksi", Intisari edisi khusus, Oktober 2002, hlm: 21

\section{Internet}

"Sejarah Singkat Cina Benteng", diakses dari

,http://agenmautau.blogspot.com/2010

/01/sejarah-singkat-cina-benteng-

3150.html. pada tanggal 22 Juni 2012

\section{Sumber Lisan/ Informan}

Oey Tjin Eng. Wawancara, 23 Febuari 2014.

Udaya Halim. Wawancara, 24 Februari 2014. 